\title{
The use of SEM/EDS method in mineralogical analysis of ordinary chondritic meteorite
}

\section{Uporaba SEM/EDS metode pri mineraloški analizi navadnega hondritnega meteorita}

\author{
Miloš MILER ${ }^{1}$, Urša CURK ${ }^{2} \&$ Breda MIRTIČ $\check{~}^{3}$
}

${ }^{1}$ Geological Survey of Slovenia, Dimičeva ulica 14, Ljubljana, SI-1000, Slovenia; e-mail: milos.miler@geo-zs.si

${ }^{2}$ Vošnjakova ulica 16, SI-1000 Ljubljana, Slovenia; e-mail: urska.curk@lj-kabel.net

${ }^{3}$ Faculty of Natural Sciences and Engineering, Department of Geology, Aškerčeva ulica 12, SI-1000 Ljubljana, Slovenia; e-mail: breda.mirtic@guest.arnes.si

Prejeto / Received 30. 11. 2009; Sprejeto / Accepted 2. 12. 2009

Key words: SEM/EDS, ordinary chondrites, mineral composition, stoichiometry

Ključne besede: SEM/EDS, navadni hondriti, mineralna sestava, stehiometrija

\begin{abstract}
The aim of this study was to evaluate the potential of scanning electron microscopy coupled with energy dispersive X-ray spectroscopy (SEM/EDS) for determination of mineral phases according to their stoichiometry and assessment of mineral composition of ordinary chondritic meteorite. For the purposes of this study, H3 type ordinary chondritic meteorite Abbott was selected. SEM/EDS allows identification and characterisation of mineral phases, whose size is below the resolution of an optical microscope. Mineral phases in chondrules and interstitial matrix were located in backscattered electron (BSE) mode and were assessed from atomic proportions of constituent elements, obtained by the EDS analysis. SEM/EDS analyses of mineral phases showed that Abbott meteorite is characterised by Fe-rich (Fe, Ni)-alloy kamacite, Fe-sulphide troilite or pyrrhotite, chromite, Mg-rich olivine, orthopyroxene bronzite or hypersthene, clinopyroxene Al-diopside, acid plagioclase oligoclase, accessory mineral chlorapatite and secondary minerals Fe-hydroxides (goethite or lepidocrocite). Results of semi-quantitative analyses confirmed that most of analysed mineral phases conform well to stoichiometric minerals with minor deviations of oxygen from stoichiometric proportions. Comparison between mineral phases in chondrules and interstitial matrix was also performed, however it showed no significant differences in elemental composition. Differences in chemical composition between minerals in interstitial matrix and chondrules are sometimes too small to be discerned by the SEM/EDS, therefore knowledge of SEM/EDS capabilities is important for correct interpretation of chondrite formation.
\end{abstract}

\section{Izvleček}

Cilj študije je bil oceniti možnost uporabe vrstičnega elektronskega mikroskopa z energijsko disperzijsko spektroskopijo rentgenskih žarkov (SEM/EDS) za določitev mineralnih faz po njihovi stehiometriji in oceno mineralne sestave navadnega hondritnega meteorita. Za raziskavo je bil uporabljen navaden hondritni meteorit tipa H3 Abbott. SEM/EDS omogoča prepoznavanje in opredelitev mineralnih faz, katerih velikost je pod ločljivostjo optičnega mikroskopa. Položaj mineralnih faz v hondrulah in medzrnski osnovi je bil določen v načinu povratno sipanih elektronov (BSE). Mineralna sestava je bila ocenjena iz atomskih razmerij sestavnih elementov, pridobljenih z EDS analizo. SEM/EDS analize mineralnih faz so pokazale, da meteorit Abbott sestavljajo (Fe, Ni)-zlitina kamacit, Fe-sulfid troilit oziroma pirotin, kromit, Mg-olivin, ortopiroksen broncit ali hipersten, klinopiroksen Al-diopsid, kisli plagioklaz oligoklaz, akcesorni mineral klorapatit in sekundarni minerali Fe-hidroksidi (goethit ali lepidokrokit). Rezultati semi-kvantitativnih analiz so pokazali, da se večina analiziranih mineralnih faz dobro ujema s stehiometričnimi minerali z manjšimi odstopanji kisika od stehiometričnih razmerij. Primerjava med mineralnimi fazami v hondrulah in medzrnski osnovi ni pokazala bistvenih razlik v elementarni sestavi. Razlike v kemični sestavi med minerali v medzrnski osnovi in hondrulah so lahko tako majhne, da jih ni možno ugotoviti s SEM/EDS. Za pravilno interpretacijo nastanka hondrita je zato pomembno poznavanje zmogljivosti SEM/EDS.

\section{Introduction}

Thorough mineralogical studies have been carried out on different chondritic meteorite samples using optical microscopy (reflected and transmis- sive) and scanning electron microscopy (SEM) coupled with energy dispersive X-ray spectroscopy (EDS) (CuRK, 2009). The aim of this study was to evaluate usefulness of SEM/EDS method for the assessment of mineral composition of or- 
dinary chondritic meteorite. Basic principles and results of mineralogical studies of chondritic meteorites using SEM/EDS and problems related to data acquisition and data interpretation are presented and discussed in this paper on a selected chondrite sample. Primary and secondary minerals, which characterise chondritic meteorites were determined.

SEM/EDS allows identification and characterisation of mineral phases in chondrules and in matrix, whose size is often below the resolution of an optical microscope. It also enables determination of microstructures in chondrules and chemical composition of microfracture-fill components. SEM/EDS is frequently a method of choice in meteorite studies worldwide.

FLOoD and co-authors (2002) carried out mineralogical and petrological researches of the Dunbogan meteorite, which revealed that it is an L6 type ordinary chondrite with mean olivine composition and pyroxene. Using SEM/EDS, chemical compositions of olivine, pyroxene, plagioclase and metal phases were determined, which were consistent with the L-group, equilibrated ordinary chondrite (FLOOD et al., 2002). ZAREK and co-authors (2004) investigated phase composition of the H5 type El Hammami chondritic meteorite using different methods including environmental scanning electron microscopy (ESEM). They established that the meteorite consists of aluminosilicates, olivine, pyroxene, kamacite and troilite. The SEM investigations showed great variations in the chemical composition of the meteorite at small distances from grain to grain. ANTONELlo and co-authors (2000) determined chemical composition of pyroxenes and olivine in the H5 type Morro de La Mina meteorite, using electron microprobe analysis, and established that magnesium-rich pyroxenes and olivine are the prevailing varieties. ChiкAmi (2002) compared chemical composition of minerals between $\mathrm{H} 3$ and $\mathrm{H} 4-5$ type enstatite chondrites using electron microprobe analysis and found out that $\mathrm{Ni}$ and $\mathrm{Si}$ contents in metal are higher in $\mathrm{H} 3$ than in $\mathrm{H} 4-5$ chondrite and that $\mathrm{Ni}$ and $\mathrm{P}$ contents in $\mathrm{H} 4-5$ chondrite are higher in matrix than in chondrules.

No study of meteorites using scanning electron microscopy and EDS X-ray microanalysis has been reported in Slovenia yet.

\section{Materials and methods}

Ordinary chondritic meteorites are non-differentiated meteorites, in which the magma (melt) has not yet differentiated. They consist of four major components: chondrules, Fe-Ni minerals, refractory inclusions of high-temperature minerals and fine-grained matrix (DAVIS, 2005). Ordinary chondritic meteorites are usually composed of principle minerals, such as olivine, rhombic and monoclinic pyroxenes, plagioclase, kamacite, taenite and troilite, and of trace minerals, such as merrillite, chromite, maskelynite, chlorapatite, quartz, ilmenite, pentlandite and metallic copper (Middlehurst \& Kuiper, 1963).
An ordinary chondritic meteorite Abbott (Fig. 1), found in 1951 in New Mexico, USA, was selected for SEM/EDS analysis. It is an olivinebronzite $\mathrm{H} 3$ type chondritic meteorite with texture of regolith breccia. H3 type chondrites contain high contents of iron (25-31 mass \%, of which 15-19 mass \% metallic iron). They are frequently unequilibrated chondrites with large differences in mineral composition of olivine and pyroxene and usually show low degree of metamorphism, because their composition and mineralogy have not changed since their formation.

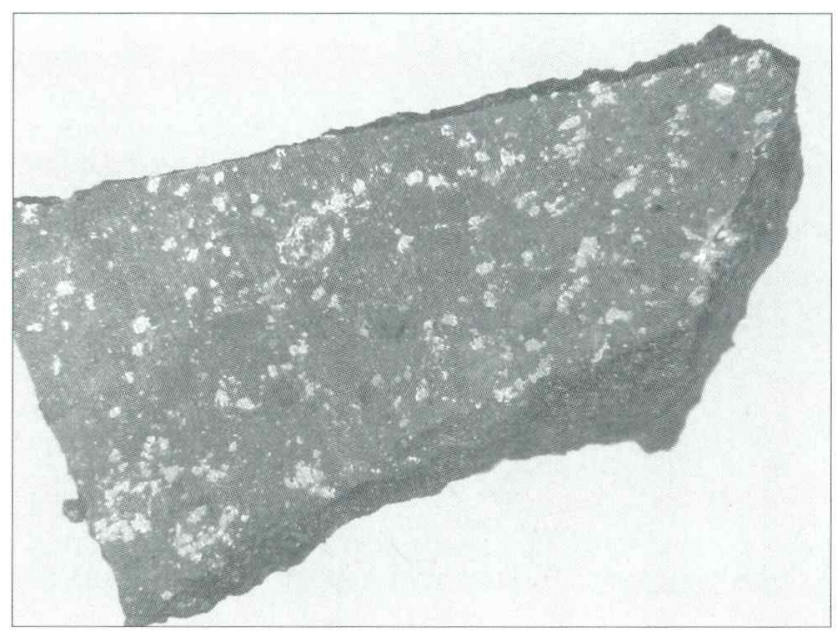

Fig. 1. The Abbott chondritic meteorite (CuRK, 2009). The size of the sample is $14 \times 8 \mathrm{~mm}$

Sl. 1. Hondritni meteorit Abbot (Curk, 2009). Velikost vzorca je $14 \times 8 \mathrm{~mm}$

Semi-quantitative EDS X-ray microanalysis was carried out on polished thin-sections of chondritic meteorite sample. Sample was impregnated with epoxy resin to improve its strength. After impregnation, the original sample was cut into thin slices, mounted on an objective glass and finely polished to $30 \mu \mathrm{m}$ thickness. The prepared polished thin-section was coated with thin layer of carbon to prevent charging and mounted on a SEM stub using double-sided carbon tape.

Minerals were located and identified using BSE mode on JEOL JSM 6490LV SEM coupled with Oxford INCA Energy EDS at accelerating voltage $20 \mathrm{kV}$ and working distance $10 \mathrm{~mm}$. Semi-quantitative EDS X-ray microanalysis was performed using EDS spot analysis with acquisition time $60 \mathrm{~s}$ and maximum process time to achieve best resolution of peaks in spectra. Mineral phases were assessed from atomic proportions of constituent elements, obtained by semi-quantitative EDS X-ray microanalysis.

X-ray spectra were optimized for quantification using cobalt optimization standard and the correction of EDS data was performed on basis of the standard ZAF-correction procedure included in the INCA Energy software(C) (OxFord InstruMENTS, 2006).

Basic principles of localisation and identification of minerals in chondritic meteorite with SEM/EDS were following. The sample was examined in the backscattered electron (BSE) mode 
that allows relative differentiation between mineral phases with different chemical composition on basis of contrast in their atomic number $\mathrm{Z}$ (atomic number contrast) (ZAREK et al., 2004; HERD et al., 2004). Atomic number $Z$ is unique for each chemical element that constitutes minerals and is a basis for BSE imaging. Mineral grains containing higher-Z elements usually appear brighter than minerals with low-Z elements (GoLdsTein et al., 2003), however the density of analysed volume also contributes to the intensity of the BSE signal. BSE signal can thus be sometimes misleading.

After localisation of mineral grains of interest with BSE imaging, qualitative and semi-quantitative chemical compositions of selected grains were measured using energy dispersive X-ray spectrometer (EDS) (ZAREK et al., 2004). EDS detects and processes X-rays that are emitted from constituent elements in the beam interaction volume and are characteristic of each chemical element, dependent on its atomic number.

Atomic proportions of constituent elements were calculated from atomic \%, obtained by the semi-quantitative EDS analysis, and compared to atomic proportions of constituent elements in stoichiometric mineral. On basis of best fit between these proportions, mineral phases were assessed. If the volume of analysed mineral phase is smaller than the interaction volume of electron beam, the beam can overlap onto adjacent phases thus producing additional $\mathrm{X}$-ray lines in spectrum that do not conform to mineral stoichiometry of the analysed phase (FLood et al., 2002).

Basic statistics of elemental composition (atomic \%) of minerals in chondrite were performed and are given in Table 1 . The number of analysed mineral grains $(\mathrm{N})$ depends on the quantity of each mineral in the sample. Mean values of atomic $\%$ are given by arithmetic mean, median and statistical dispersion by range, arithmetic standard deviation and coefficient of variation.

All scanning electron microscopy and energy dispersive spectrometry investigations were performed in laboratory at Geological Survey of Slovenia.

\section{Results and discussion}

SEM/EDS analyses of chemical composition of mineral phases in porphyritic olivine (PO) and barred olivine (BO) chondrules, interstitial matrix and interchondrule matrix were carried out. Chemical compositions of constituent mineral phases in chondrules and interstitial matrix were compared.

Using SEM/EDS analysis, we successfully identified and classified mineral phases (Curk, 2009), such as primary metallic mineral kamacite, sulphide mineral troilite or pyrrhotite, oxide mineral chromite and secondary minerals, which formed during oxidation of metallic minerals, such as Fehydroxides (goethite or lepidocrocite). Primary silicate minerals are represented by olivine (forsterite-fayalite), pyroxenes (bronzite or hyper- sthene), acid plagioclase (oligoclase) and accessory mineral apatite.

\section{Kamacite}

Kamacite appears brighter than other metallic minerals in the BSE mode. It occurs mostly in the form of large irregularly shaped (xenomorphic) grains in the interstitial matrix of the chondrite and rarely in the $\mathrm{PO}$ chondules. It can also be found as a fill in some microfractures, between mineral grains and around chondrule boundaries (Curk, 2009). Kamacite is usually associated with troilite and is commonly rimmed by Fe-hydroxides (goethite or lepidocrocite) as a result of its oxidation (Fig. 2).

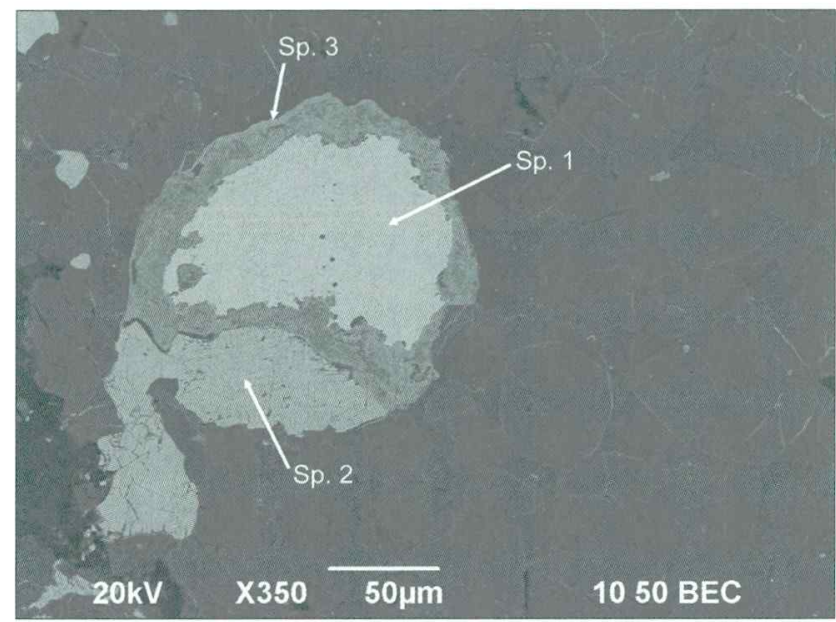

Fig. 2. BSE image of kamacite grain (Sp. 1 - spectrum 1) rimmed by thick layer of Fe-hydroxide (goethite, lepidocrocite) (Sp. 3 - spectrum 3) and associated with troilite (Sp. 2 - spectrum 2) in a PO chondrule

Sl. 2. BSE slika zrna kamacita (Sp. 1 - spectrum 1) obdanega s plastjo Fe-hidroksida (goethit, lepidokrokit) (Sp. 3 spectrum 3) v združbi s troilitom (Sp. 2 - spectrum 2) v PO hondruli

Kamacite grains were measured in interstitial matrix and in PO chondrule. EDS X-ray spectrum of kamacite in $\mathrm{PO}$ chondrule shows peaks of major elements Fe and Ni (Fig. 3). Results of semi-quantitative X-ray analysis of kamacite in interstitial matrix are listed in Table 1 . They indicate that the composition of $\mathrm{Fe}-\mathrm{Ni}$ alloy corresponds to mineral kamacite $(\mathrm{Fe}, \mathrm{Ni})$, since it contains 6.5 atomic \% (approximately 6 weight \%) of $\mathrm{Ni}$, which is typical of kamacite (MARFUnIN, 1998; ZAREK et al., 2004;

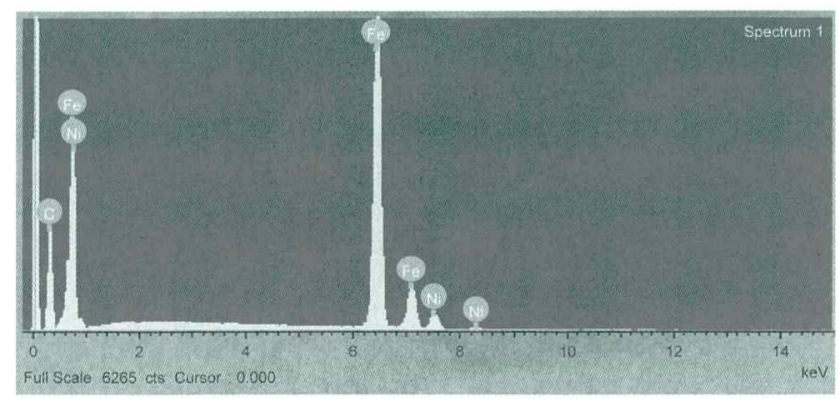

Fig. 3. X-ray spectrum of kamacite (Sp. 1 - spectrum 1) S1. 3. Spekter kamacita (Sp. 1 - spectrum 1) 
Reyes-Salas et al., 2007). Standard deviations of mean atomic \% of constituent elements in matrix kamacite are relatively low and show good repeatability of measurements (Tab. 1). Comparison between elemental compositions of matrix kamacite and chondrule kamacite revealed no significant differences in atomic \%.

\section{Troilite, pyrrhotite}

Troilite appears darker compared to kamacite and brighter than chromite in the BSE mode (Fig. 2). It occurs mostly as irregularly shaped grains, associated with kamacite in the interstitial matrix and rarely in chondrules. Inclusions of chromite and apatite sometimes occur in larger troilite grains. Troilite surface is frequently rather fractured.

EDS analyses of troilite in interstitial matrix and PO chondrule were carried out. EDS X-ray spectrum of chondrule troilite shows distinctive peaks of major elements Fe and S (Fig. 4). Results of semi-quantitative EDS X-ray microanalyses of matrix troilite are listed in Table 1 . They indicate that the atomic ratio between $\mathrm{Fe}$ and $\mathrm{S}$ in iron sulphide, presumed troilite, amounts to 0.83 and corresponds very well to pyrrhotite stoichiometry $\left(\mathrm{Fe}_{1-\mathrm{x}} \mathrm{S} ;(\mathrm{x}=0-0.17)\right)$ rather than pure troilite $(\mathrm{FeS})$ (Tab. 1). Semi-quantitative results of troilite in PO chondrule gave similar composition compared to troilite in interstitial matrix.

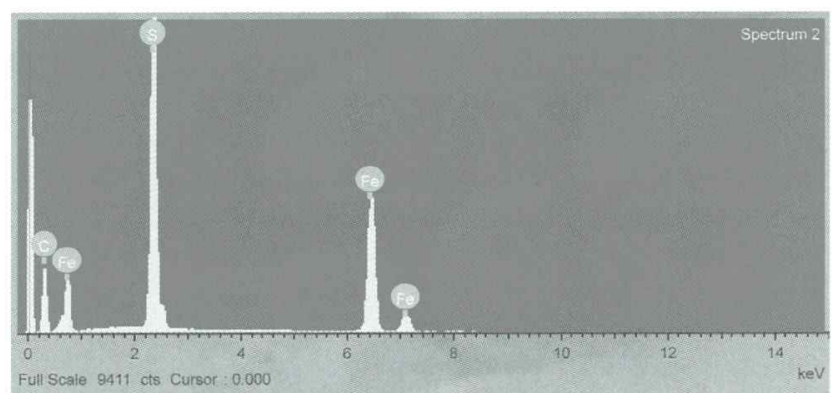

Fig. 4. X-ray spectrum of troilite (Sp. 2 - spectrum 2)

Sl. 4. Spekter troilita (Sp. 2 - spectrum 2)

\section{Chromite}

Chromite was found as individual grains in interstitial matrix, rarely associated with other metallic minerals, and as small subhedral grains around olivine crystals in chondrules. Chromite also occurs as narrow veinlets or fills microfractures between and across olivine and pyroxene grains in chondrules. Generally, it is much less subject to oxidation processes than kamacite (Fig. 5).

Chromite grains were measured only in interstitial matrix. The EDS X-ray spectrum of chromite exhibits low intensity Ti peaks (Fig. 6). Semi-quantitative analysis shows low contents of Ti, which is considered as trace element in chromite that usually accompanies Fe (Tab. 1). The atomic ratio between $\mathrm{Cr}$ and $\mathrm{Fe}$ conforms very well to chromite $\left(\mathrm{FeCr}_{2} \mathrm{O}_{4}\right)$ and deviates from the $\mathrm{Cr} / \mathrm{Fe}$ ratio in stoichiometric chromite only by 0.04 (Tab. 1).

Rather high $\mathrm{Mg}$ and $\mathrm{Al}$ peaks are also apparent in the spectrum (Fig. 6). Semi-quantitative results

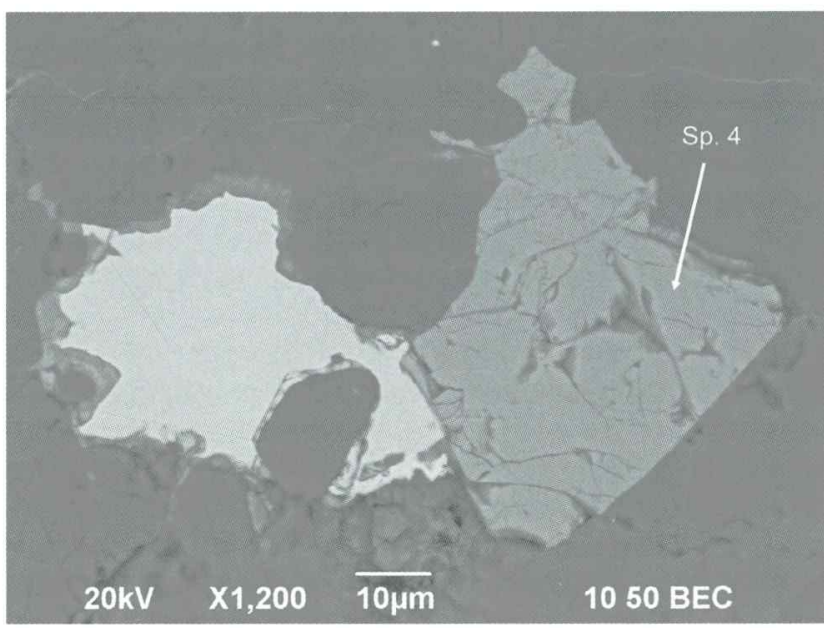

Fig. 5. BSE image of chromite grain (Sp. 4 - spectrum 4) associated with kamacite (brighter grain, left) in interstitial matrix

Sl. 5. BSE slika zrna kromita (Sp. 4 - spectrum 4) v združbi s kamacitom (svetlo zrno, levo) v medzrnski osnovi

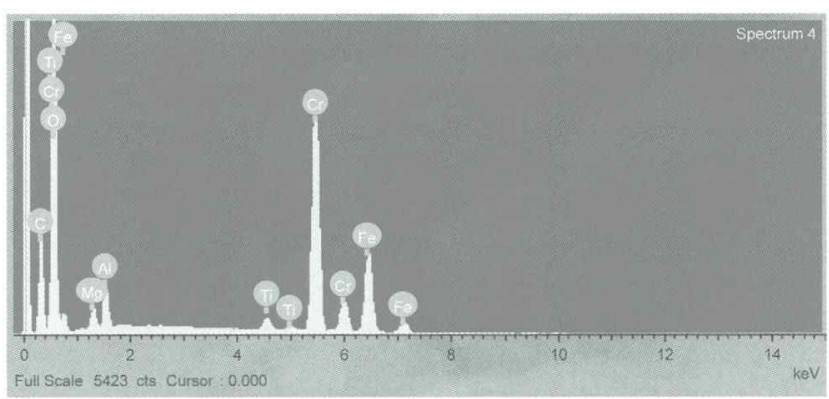

Fig. 6. X-ray spectrum of chromite (Sp. 4 - spectrum 4) S1. 6. Spekter kromita (Sp. 4 - spectrum 4)

show that the atomic ratio between $\mathrm{Al}$ and $\mathrm{Mg}$ is close to spinel stoichiometry (the atomic ratio between $\mathrm{Al}$ and $\mathrm{Mg}$ differs from the $\mathrm{Al} / \mathrm{Mg}$ ratio in stoichiometric spinel by 0.75 ). Since chromite also belongs to spinel group, it is possible that Fe and $\mathrm{Cr}$ in chromite crystal lattice were partly replaced by $\mathrm{Mg}$ and $\mathrm{Al}$.

\section{Fe-hydroxides (goethite or lepidocrocite)}

They commonly occur in the form of oxidation layers around kamacite grains (Fig. 2), those in interstitial matrix and those in chondrules (CuRK, 2009), and rarely around troilite grains.

The EDS X-ray spectrum of Fe-hydroxide surrounding kamacite in PO chondrule shows presence of smaller $\mathrm{Ni}$ peaks (Fig. 7). Ni is a residual element of kamacite oxidation. There is also a possibility that $\mathrm{Ni}$ originates from the adjacent kamacite, since the electron beam can overlap onto adjacent phases (FLOOD et al., 2002).

Results of semi-quantitative EDS analyses of Fe-hydroxides in interstitial matrix are shown in Table 1. Quantification and interpretation of semi-quantitative EDS analysis of light elements is usually very difficult. O commonly binds with $\mathrm{C}$ and forms organic molecules, which are adsorbed onto sample surface as contamination layer. $\mathrm{H}$ cannot be detected by the EDS at all. Despite these facts, the atomic ratio between $\mathrm{O}$ and $\mathrm{Fe}$ 
Tab. 1 Elemental composition of $\mathrm{N}$ minerals in chondrite; mean atomic \% (x (at. \%)), median (Me), range (min-max), standard deviation $\left(\sigma^{\text {at }}(\%)\right)$, coefficient of variation $(\mathrm{CV})$, composition of stoichiometric mineral in atomic \% (st. min (at.\%)), number of atoms in analyzed mineral (anal. at. no.), number of atoms in stoichiometric mineral (st. at. no.)

Tab. 1 Elementarna sestava N mineralov v hondritu; aritmetična sredina atomskih \% (x (at.\%)), mediana (Me), razpon (min-max), standardni odklon $\left(\sigma^{\text {at }}(\%)\right)$, koeficient variacije $(\mathrm{CV})$, sestava stehiometričnega minerala atomski \% (st. min. (at. \%)), śtevilo atomov analiziranega minerala (anal. at. no.), število atomov stehiometričnega minerala (st. at. no.)

\begin{tabular}{|c|c|c|c|c|c|c|c|c|}
\hline element & $x($ at. $\%)$ & $\mathrm{Me}$ & $\min -\max$ & $\sigma^{\text {at }}(\%)$ & CV & st. min. (at. \%) & anal. at. no. & st. at. no. \\
\hline \multicolumn{9}{|c|}{ Kamacite ( $N=14)$} \\
\hline $\mathrm{Fe}$ & 93.47 & 93.52 & $93.64-94.27$ & 0.370 & 0.00 & 93.60 & 14.31 & 14.62 \\
\hline $\mathrm{Ni}$ & 6.53 & 6.48 & $6.36-7.31$ & 0.370 & 0.06 & 6.40 & 1.00 & 1.00 \\
\hline \multicolumn{9}{|c|}{ Troilite $(\mathrm{N}=20)$} \\
\hline $\mathrm{S}$ & 54.53 & 53.95 & $53.24-57.06$ & 1.282 & 0.02 & 50.00 & 1.20 & 1.00 \\
\hline $\mathrm{Fe}$ & 45.47 & 46.05 & $42.94-46.76$ & 1.282 & 0.03 & 50.00 & 1.00 & 1.00 \\
\hline \multicolumn{9}{|c|}{ Fe-hydroxide $(\mathrm{N}=13)$} \\
\hline $\mathrm{H}$ & - & - & - & - & - & 24.89 & - & 0.99 \\
\hline 0 & 72.12 & 74.51 & $63.44-77.18$ & 4.562 & 0.06 & 50.07 & 2.80 & 2.00 \\
\hline $\mathrm{Fe}$ & 25.76 & 24.45 & $12.26-35.63$ & 5.796 & 0.23 & 25.04 & 1.00 & 1.00 \\
\hline $\mathrm{Ni}$ & 2.13 & 1.42 & $0.49-10.55$ & 2.608 & 1.23 & - & 0.08 & - \\
\hline \multicolumn{9}{|c|}{ Chromite $(\mathrm{N}=20)$} \\
\hline $\mathrm{O}$ & 63.71 & 63.76 & $62.94-64.41$ & 0.353 & 0.01 & 57.14 & 6.17 & 4.00 \\
\hline $\mathrm{Mg}$ & 2.28 & 2.20 & $1.61-2.85$ & 0.359 & 0.16 & - & 0.22 & - \\
\hline Al & 2.86 & 2.84 & $2.27-3.41$ & 0.362 & 0.13 & - & 0.28 & - \\
\hline $\mathrm{Ti}$ & 0.73 & 0.77 & $0.42-0.84$ & 0.109 & 0.15 & - & 0.07 & - \\
\hline $\mathrm{Cr}$ & 20.11 & 20.12 & $19.51-21.17$ & 0.425 & 0.02 & 28.57 & 1.95 & 2.00 \\
\hline $\mathrm{Fe}$ & 10.32 & 10.32 & $9.64-10.83$ & 0.358 & 0.03 & 14.29 & 1.00 & 1.00 \\
\hline \multicolumn{9}{|c|}{ Olivine ( $N=21)$} \\
\hline $\mathrm{O}$ & 62.11 & 62.15 & $61.45-62.45$ & 0.249 & 0.00 & 57.14 & 4.78 & 4.00 \\
\hline $\mathrm{Mg}$ & 20.56 & 20.59 & $19.86-20.91$ & 0.261 & 0.01 & 22.86 & 1.58 & 1.60 \\
\hline $\mathrm{Si}$ & 12.99 & 12.97 & $12.82-13.23$ & 0.114 & 0.01 & 14.28 & 1.00 & 1.00 \\
\hline $\mathrm{Fe}$ & 4.34 & 4.33 & $4.08-4.82$ & 0.221 & 0.05 & 5.71 & 0.33 & 0.40 \\
\hline \multicolumn{9}{|c|}{ Chlorapatite $(\mathrm{N}=17)$} \\
\hline $\mathrm{O}$ & 63.60 & 63.54 & $62.02-65.95$ & 0.998 & 0.02 & 57.14 & 14.03 & 12.00 \\
\hline $\mathrm{P}$ & 13.60 & 13.71 & $12.90-14.04$ & 0.330 & 0.02 & 14.28 & 3.00 & 3.00 \\
\hline $\mathrm{Cl}$ & 3.84 & 3.83 & $3.33-4.38$ & 0.255 & 0.07 & 4.76 & 0.85 & 1.00 \\
\hline $\mathrm{Ca}$ & 18.97 & 18.92 & $17.69-19.90$ & 0.540 & 0.03 & 23.81 & 4.19 & 5.00 \\
\hline \multicolumn{9}{|c|}{ Pyroxene $(\mathrm{N}=20)$} \\
\hline $\mathrm{O}$ & 64.52 & 64.45 & $64.10-65.01$ & 0.293 & 0.00 & 60.00 & 7.13 & 6.00 \\
\hline $\mathrm{Mg}$ & 14.62 & 14.69 & $12.94-16.16$ & 0.546 & 0.04 & 10.00 & 1.62 & 1.00 \\
\hline $\mathrm{Si}$ & 18.09 & 18.12 & $17.80-18.50$ & 0.207 & 0.01 & 20.00 & 2.00 & 2.00 \\
\hline $\mathrm{Ca}$ & 0.19 & 0.19 & $0.04-0.28$ & 0.063 & 0.33 & - & 0.02 & - \\
\hline $\mathrm{Fe}$ & 2.59 & 2.57 & $1.43-3.90$ & 0.411 & 0.16 & 10.00 & 0.29 & 1.00 \\
\hline \multicolumn{9}{|c|}{ Forsterite $(\mathrm{N}=4)$} \\
\hline $\mathrm{O}$ & 61.14 & 61.29 & $60.66-61.34$ & 0.324 & 0.01 & 57.15 & 4.69 & 4.00 \\
\hline $\mathrm{Mg}$ & 25.23 & 25.20 & $24.88-25.62$ & 0.333 & 0.01 & 28.57 & 1.93 & 2.00 \\
\hline $\mathrm{Si}$ & 13.04 & 13.01 & $12.96-13.19$ & 0.105 & 0.01 & 14.28 & 1.00 & 1.00 \\
\hline $\mathrm{Fe}$ & 0.60 & 0.64 & $0.34-0.78$ & 0.202 & 0.34 & - & 0.05 & - \\
\hline \multicolumn{9}{|c|}{ Diopside $(\mathrm{N}=4)$} \\
\hline $\mathrm{O}$ & 64.22 & 64.20 & $63.99-64.51$ & 0.234 & 0.00 & 60.00 & 10.12 & 6.00 \\
\hline $\mathrm{Mg}$ & 8.92 & 8.93 & $8.17-9.64$ & 0.629 & 0.07 & 10.00 & 1.41 & 1.00 \\
\hline $\mathrm{Al}$ & 3.21 & 3.19 & $2.61-3.86$ & 0.529 & 0.16 & - & 0.51 & - \\
\hline $\mathrm{Si}$ & 16.84 & 16.81 & $16.46-17.28$ & 0.386 & 0.02 & 20.00 & 2.65 & 2.00 \\
\hline $\mathrm{Ca}$ & 6.35 & 6.77 & $4.83-7.01$ & 1.023 & 0.16 & 10.00 & 1.00 & 1.00 \\
\hline \multicolumn{9}{|c|}{ Plagioclase $(\mathrm{N}=20)$} \\
\hline $\mathrm{O}$ & 66.49 & 66.45 & $65.50-68.30$ & 0.669 & 0.01 & 61.54 & 10.67 & 8.00 \\
\hline $\mathrm{Al}$ & 7.23 & 7.23 & $6.89-7.88$ & 0.228 & 0.03 & 8.46 & \multirow{2}{*}{4.32} & \multirow{2}{*}{4.00} \\
\hline $\mathrm{Si}$ & 19.68 & 19.73 & $18.56-20.50$ & 0.488 & 0.02 & 22.30 & & \\
\hline $\mathrm{K}$ & 0.37 & 0.32 & $0.24-1.26$ & 0.214 & 0.57 & - & 0.06 & - \\
\hline $\mathrm{Na}$ & 5.53 & 5.57 & $4.81-6.21$ & 0.321 & 0.06 & 6.92 & \multirow{2}{*}{1.00} & \multirow{2}{*}{1.00} \\
\hline $\mathrm{Ca}$ & 0.70 & 0.73 & $0.10-0.84$ & 0.167 & 0.24 & 0.77 & & \\
\hline
\end{tabular}

conforms rather well to stoichiometric mineral goethite or lepidocrocite $(\mathrm{FeO}(\mathrm{OH}))$ (Tab. 1). Very high standard deviations of constituent elements reflect changeable composition of Fe-hydroxides, which is a consequence of different oxidation levels of kamacite regardless of its position in the chondrite (interstitial matrix or chondrules). The composition of Fe-hydroxides in interstitial ma- 
trix is namely similar to that of Fe-hydroxides in chondrules.

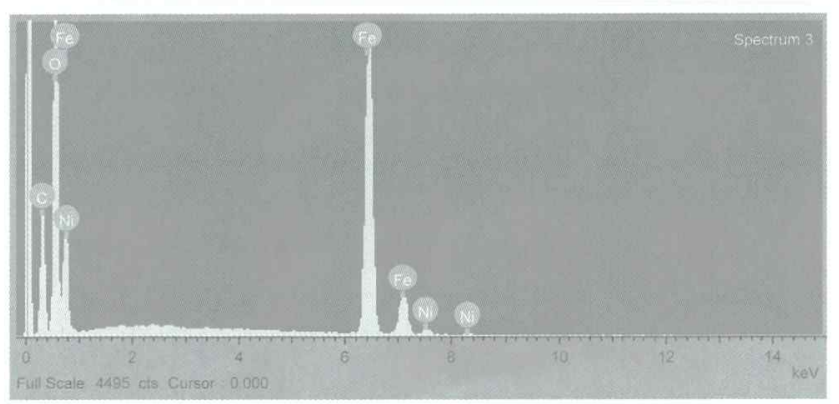

Fig. 7. X-ray spectrum of oxidation products of kamacite (Fe-hydroxide) (Sp. 3 - spectrum 3)

Sl. 7. Spekter produktov oksidacije kamacita (Fe-hidroksid)

\section{Olivine}

Besides pyroxene, olivine represents one of the most abundant mineral phases, constituting interstitial matrix (Fig. 8), which binds chondrules together and is the prevalent mineral in chondrules (Fig. 10). Olivine occurs in the form of larger grains in plagioclase matrix, indicating that olivine crystallised before plagioclase. It is mostly represented by Mg-rich solid solutions of forsteri-

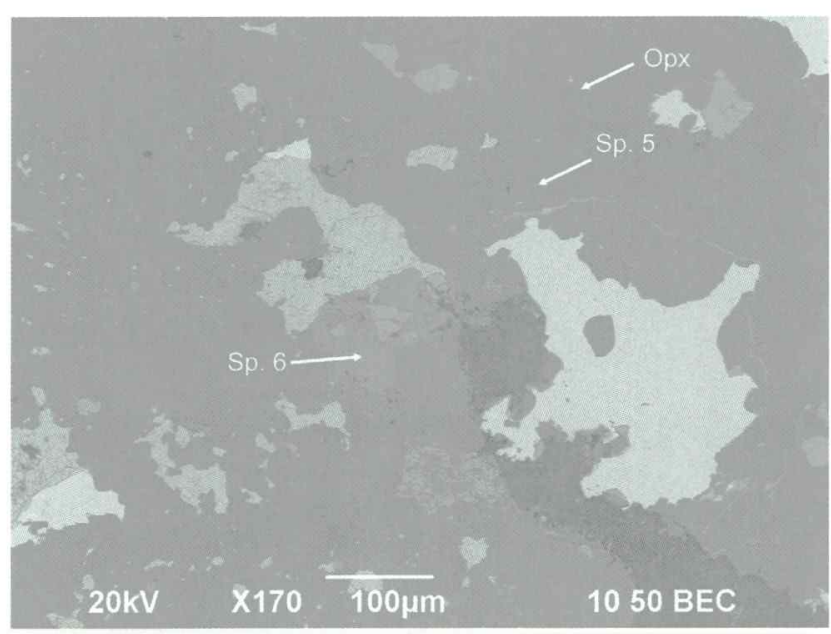

Fig. 8. BSE image of olivine (Sp. 5 - spectrum 5), chlorapatite (Sp. 6 - spectrum 6) and pyroxene (Opx) grains in interstitial matrix

Sl. 8 BSE slika olivina (Sp. 5 - spectrum 5), klorapatita

(Sp. 6 - spectrum 6) in piroksena (Opx) v medzrnski osnovi

te $\left(\mathrm{Mg}_{2} \mathrm{SiO}_{4}\right)$ and fayalite $\left(\mathrm{Fe}_{2} \mathrm{SiO}_{4}\right)$. Only in some $\mathrm{BO}$ chondrules, pure forsterite (Tab. 1) was also identified. Olivine grains in chondrules are sometimes fractured and filled mostly by metallic mineral phases.

EDS X-ray analyses of olivine in BO chondrules and in interstitial matrix were carried out. The EDS X-ray spectrum of olivine in interstitial matrix exhibits relatively pure composition (Fig. 9). Semi-quantitative results for interstitial olivine are shown in Table 1 . The atomic ratio between (Mg, Fe) and Si conforms very well to the stoichiometry of olivine ( $\mathrm{Mg}, \mathrm{Fe})_{2} \mathrm{SiO}_{4}$ ) and differs from $(\mathrm{Mg}, \mathrm{Fe}) / \mathrm{Si}$ ratio in stoichiometric olivine by 0.08 (Tab. 1). The atomic ratio between $\mathrm{O}$ and $\mathrm{Si}$ devia-

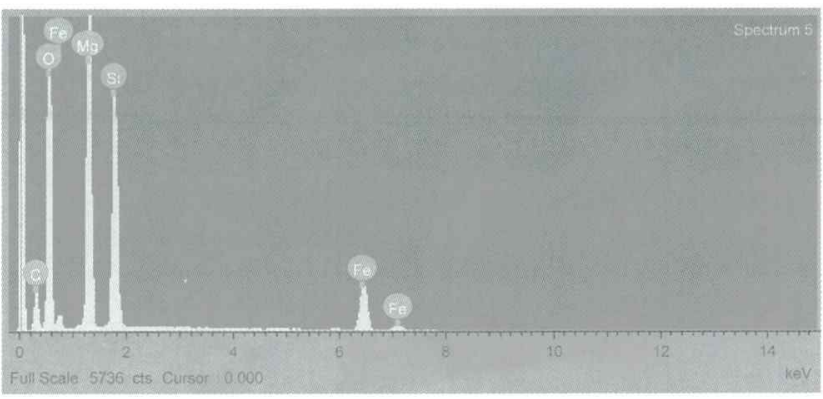

Fig. 9. X-ray spectrum of olivine in interstitial matrix (Sp. 5 - spectrum 5)

Sl. 9. Spekter olivina v medzrnski osnovi (Sp. 5 - spectrum 5)

tes from the O/Si ratio in stoichiometric olivine by 0.78 . However, the small coefficient of variation reflects very small variance of mean atomic $\%$ of constituent elements and shows very good repeatability of measurements. This means that the differences in atomic ratios between measured and stoichiometric olivine are a consequence of the systematic error of the EDS in light element quantification.

The EDS X-ray spectrum and semi-quantitative results of olivine in $\mathrm{BO}$ chondrule gave similar composition, compared to olivine in interstitial matrix. Olivine in $\mathrm{BO}$ chondrule contains approximately 4.7 atomic \% more $\mathrm{Mg}$ and 4 atomic $\%$ less $\mathrm{Fe}$, however $(\mathrm{Mg}, \mathrm{Fe}) / \mathrm{Si}$ and $\mathrm{O} / \mathrm{Si}$ atomic ratios remain similar to the olivine in interstitial matrix and correspond to the stoichiometry of olivine.

\section{Pyroxenes}

Pyroxenes are mostly represented by orthopyroxene. Orthopyroxene in chondrules and interstitial matrix is commonly associated with olivine, which crystallised first (Figs. 8, 10). Clinopyroxene also occurs in chondrules. Pyroxene grains in chondrules are large and usually fractured.

EDS X-ray analyses of pyroxenes in BO chondrule and in interstitial matrix showed rather con-

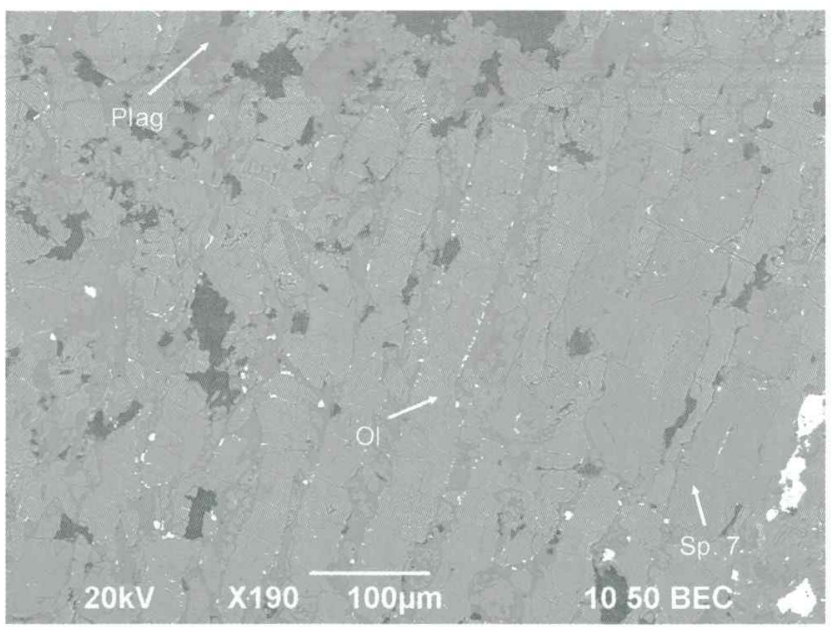

Fig. 10. Detail of BO chondrule (BSE image). Olivine crystals $(\mathrm{Ol})$ associated with pyroxene (Sp. 7 - spectrum 7 ) in plagioclase matrix (Plag)

Sl. 10. Detajl BO hondrule (BSE slika). Kristali olivina (Ol) v združbi s piroksenom (Sp. 7 - spectrum 7) v plagioklazni osnovi (Plag) 
sistent composition of pyroxenes. Low intensity $\mathrm{Ca}$ peaks can be seen in the EDS X-ray spectrum of chondrule pyroxene (Fig. 11). Ca commonly substitutes Mg in pyroxene crystal lattice. Matrix pyroxenes contain small contents of $\mathrm{Mn}$, which is commonly present in pyroxenes as minor or trace element (FLOOD et al., 2002).

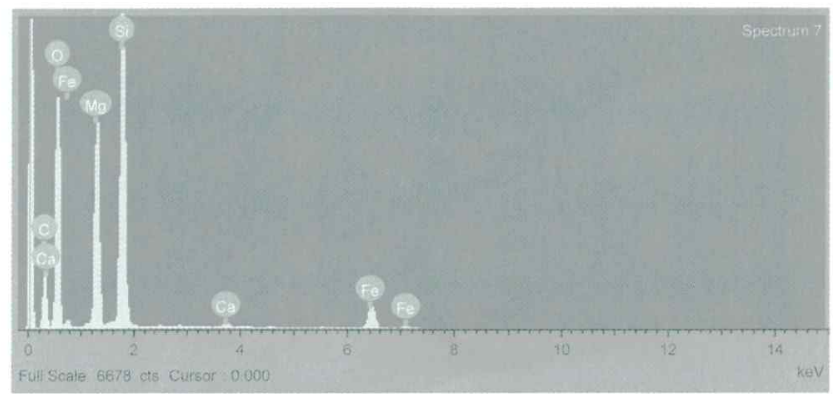

Fig. 11. X-ray spectrum of pyroxene (bronzite or hypersthene) (Sp. 7 - spectrum 7)

Sl. 11. Spekter piroksena (broncit ali hipersten) (Sp. 7 - spectrum 7)

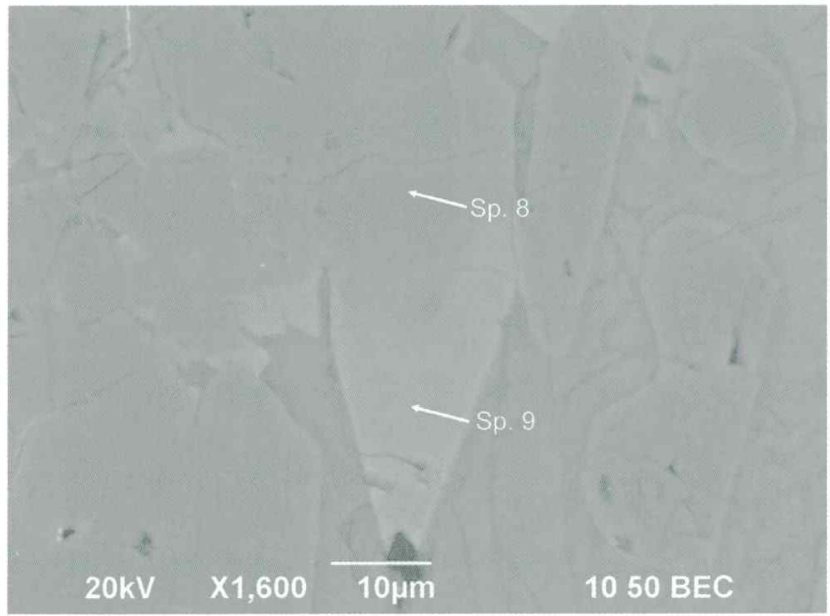

Fig. 12. BSE image of olivine (forsterite) (Sp. 8 - spectrum 8) and presumably Al-rich diopside (Sp. 9 - spectrum 9) in a BO chondrule

Sl. 12. BSE slika olivina (forsterita) (Sp. 8 - spectrum 8) in domnevno Al-diopsida (Sp. 9 - spectrum 9) v BO hondruli

Pyroxenes, listed in Table 1, were measured in interstitial matrix. Semi-quantitative results of matrix pyroxenes (Tab. 1) and chondrule pyroxenes show that $\mathrm{Ca}$ contents are very low, which corresponds to low-Ca pyroxenes (FLOOD et al., 2002; ZAREK et al., 2004). The content of Fe in the chondrule pyroxene is a bit lower than in matrix pyroxene. Atomic ratios between ( $\mathrm{Mg}, \mathrm{Fe}, \mathrm{Ca})$ and $\mathrm{Si}$ in chondrule and in matrix pyroxenes conform rather well to stoichiometry of hypersthene or bronzite $\left((\mathrm{Fe}, \mathrm{Mg})_{2} \mathrm{Si}_{2} \mathrm{O}_{6}\right)$ or even clinopyroxene pigeonite and deviate from the ratio in stoichiometric pyroxene only by 0.07 and 0.04 , respectively. Since the content of $\mathrm{Ca}$ is very low (less than 1 atomic \%) the mineral is certainly not pigeonite. The O/Si ratio in matrix (Tab. 1) and in chondrule deviates from pyroxene stoichiometry by 0.47 and 0.57 , respectively.

In some $\mathrm{BO}$ chondrules, forsterite $\left(\mathrm{Mg}_{2} \mathrm{SiO}_{4}\right)$ passes gradually into $(\mathrm{Ca}, \mathrm{Al})$-rich phase, per- haps Al-rich diopside ( $\mathrm{CaMg}(\mathrm{Si}, \mathrm{Al})_{2} \mathrm{O}_{6}$ (NuTH et al., 2005) (Figs. 12, 13, 14; Tab. 1). The EDS $\mathrm{X}$-ray spectrum of Al-rich diopside (Fig. 14) exhibits small peaks of $\mathrm{Ti}$ and $\mathrm{Cr}$, which were interpreted as common impurities in diopside. However, $\mathrm{Ti}$ and $\mathrm{Cr}$ were not quantified.

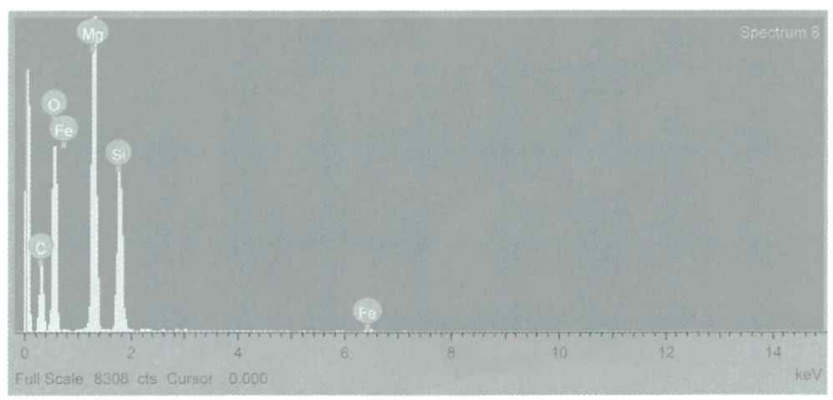

Fig. 13. X-ray spectrum of olivine (forsterite)

(Sp. 8 - spectrum 8)

S1. 13. Spekter olivina (forsterita) (Sp. 8 - spectrum 8)

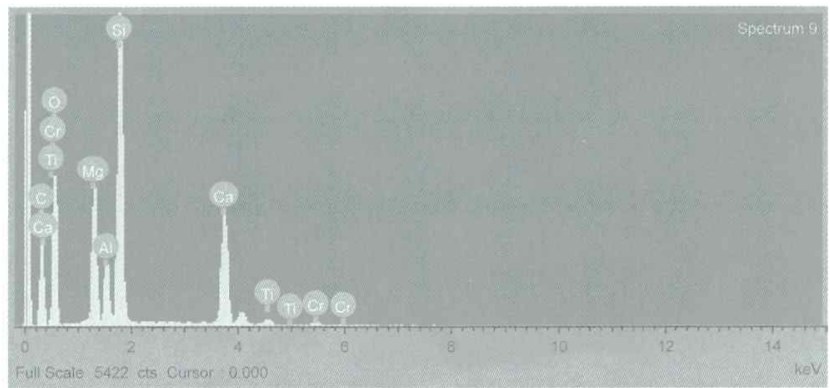

Fig. 14. X-ray spectrum of presumed Al-rich diopside (Sp. 9 - spectrum 9)

Sl. 14. Spekter domnevno Al-diopsida (Sp. 9 - spectrum 9)

\section{Plagioclase}

Anhedral plagioclase grains mostly fill interstitial voids between olivine and pyroxene grains and form interstitial (Fig. 15) and interchondrule (Fig. 10) matrices. It has a consistent composition.

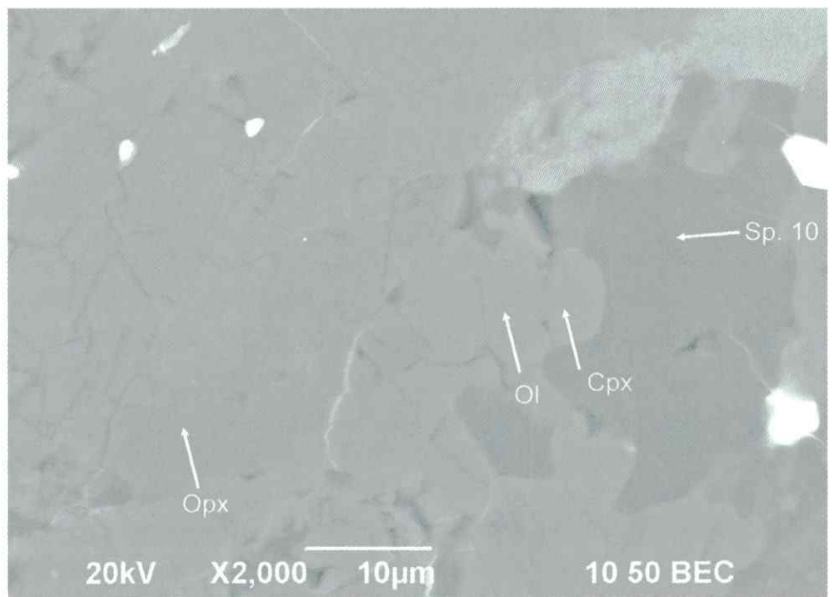

Fig. 15. BSE image of plagioclase (oligoclase) (Sp. $10-$ spectrum 10) representing interstitial matrix between grains of olivine (Ol), chlorapatite (Ap), diopside ( $\mathrm{Cpx}$ ) and bronzite or hypersthene (Opx)

Sl. 15. BSE slika plagioklaza (oligoklaz) (Sp. 10 - spectrum $10)$, ki predstavlja medzrnsko osnovo med zrni olivina (Ol), klorapatita $(\mathrm{Ap})$, diopsida $(\mathrm{Cpx})$ in broncita ali hiperstena (Opx) 
EDS X-ray analysis of plagioclase in interstitial matrix, listed in Table 1 , shows that it compositionally corresponds to $\mathrm{Na}$-rich acid plagioclase. The EDS X-ray spectrum of plagioclase shows low intensity $\mathrm{K}$ and $\mathrm{Ca}$ peaks (Fig. 16). Na in plagioclase crystal structure is often partially replaced by $\mathrm{Ca}$ or $\mathrm{K}$. The plagioclase contains more than 0.62 atomic \% of $\mathrm{Ca}$ and less than 5.6 atomic \% of $\mathrm{Na}$ (more than $10 \%$ of $\mathrm{Na}$ is replaced by $\mathrm{Ca}$ ), which by definition (AnTHONY et al., 1995) corresponds to the mineral oligoclase ((Na, Ca) $(\mathrm{Si}$, $\mathrm{Al}_{4} \mathrm{O}_{8}$ ) with small amounts of $\mathrm{K}$ (Tab. 1). Atomic ratios between $(\mathrm{Na}, \mathrm{Ca}, \mathrm{K})$ and $(\mathrm{Si}, \mathrm{Al})$ in interstitial matrix and in chondrule correspond well to stoichiometry of oligoclase, differing from the ratio in stoichiometric oligoclase by 0.01 . The $\mathrm{O} /(\mathrm{Si}$, $\mathrm{Al})$ ratios in matrix and in chondrule deviate from $\mathrm{O} /(\mathrm{Si}, \mathrm{Al})$ ratios (8:4) in stoichiometric oligoclase by 0.47 and 0.38 , respectively.

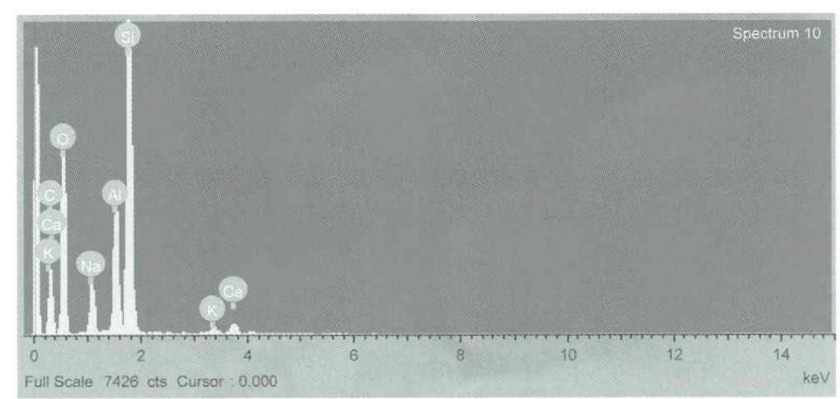

Fig. 16. X-ray spectrum of plagioclase (oligoclase with small amount of K) (Sp. 10 - spectrum 10)

Sl. 16. Spekter plagioklaza (oligoklaz z manjšo vsebnostjo K) (Sp. 10 - spectrum 10)

\section{Apatite}

Apatite is an accessory phosphate mineral occurring in the form of rather large and mostly subhedral grains in interstitial matrix of the chondrite (Fig. 17). It is usually associated with plagioclase and fills voids between olivine grains.

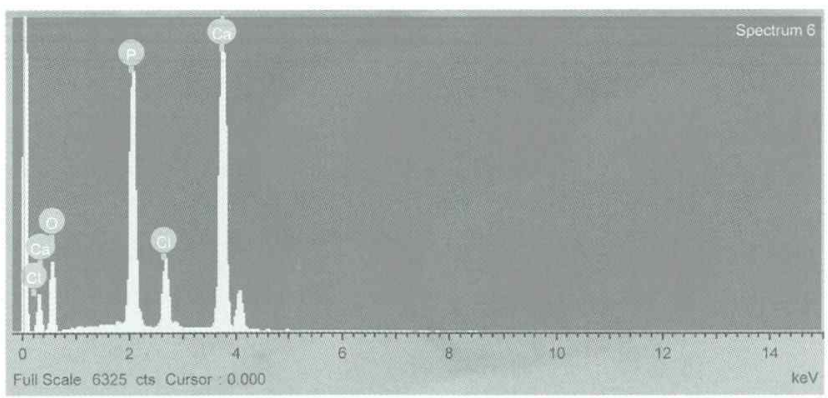

Fig. 17. X-ray spectrum of chlorapatite (Sp. 6 - spectrum 6)

Sl. 17. Spekter klorapatita (Sp. 6 - spectrum 6)

Major elements $\mathrm{Ca}, \mathrm{P}, \mathrm{O}$ and $\mathrm{Cl}$ are obvious in the EDS X-ray spectrum of apatite (Fig. 10). Semi-quantitative analysis shows that the composition of apatite is consistent with the stoichiometry of chlorapatite $\left(\mathrm{Ca}_{5}\left(\mathrm{PO}_{4}\right)_{3} \mathrm{Cl}\right)$ (Tab. 1). The atomic ratio between $\mathrm{Ca}$ and $\mathrm{P}$ in the analysed mineral phase deviates from the stoichiometry of chlorapatite by 0.28 , the ratio between $\mathrm{Ca}$ and $\mathrm{Cl}$ deviates by approximately 0.062 and the ratio between $\mathrm{O}$ and $\mathrm{P}$ by 0.68 .

\section{Conclusions}

Results of SEM/EDS analyses of mineral phases in ordinary chondritic meteorite demonstrated usefulness of this method for identification and characterisation of mineral phases whose size is often below the resolution of an optical microscope.

Semi-quantitative analyses of metallic phases showed that they mostly belong to iron-rich Fe-Ni alloy kamacite. The composition of iron sulphide, presumed troilite, corresponds to pyrrhotite stoichiometry rather than troilite. Fe-hydroxides, which were formed as a result of kamacite oxidation, contain small amounts of Ni. The atomic ratio between $\mathrm{O}$ and $\mathrm{Fe}$ in Fe-hydroxides corresponds stoichiometrically to goethite or lepidocrocite, although $\mathrm{H}$ cannot be detected by the EDS. The atomic ratio between $\mathrm{Cr}$ and $\mathrm{Fe}$ in iron chromium oxide corresponds well to chromite, which contains small amounts of $\mathrm{Mg}$ and $\mathrm{Al}$ (stoichiometrically spinel) in its crystal lattice. Semiquantitative analyses of olivine and pyroxenes are in agreement with Mg-rich solid solutions of forsterite and fayalite and with hypersthene or bronzite, respectively. Plagioclase compositionally corresponds to oligoclase with small amounts of $\mathrm{K}$, which can also be present in oligoclase crystal lattice. Elemental composition of apatite is consistent with chlorapatite.

According to semi-quantitative results of SEM/ EDS analyses, it can be concluded that SEM/EDS possesses adequate accuracy to obtain stoichiometric mineral from atomic ratios of constituent elements and identify analysed mineral phases.

Comparison between mineral phases in interstitial matrix and in chondrules showed no significant differences in elemental composition. Differences in chemical composition between interstitial matrix and chondrules are important for interpretation of chondrite formation, however they are sometimes too small to be discerned by the SEM/EDS.

\section{Acknowledgements}

Authors would like to express sincere gratitude to Mr. Albin Smrke for letting us analyze a sample of Abbott meteorite from his private collection.

\section{References}

Anthony, J. W., Bideaux, R. A., Bladh, K. W. \& NiCHols, M. C. 1995: The Handbook of Mineralogy, Vol. II: Silica, Silicates. Mineral Data Publishing (Tucson): 1-904.

Antonello, L. L, Scorzelli, R. B., Azevedo, I. S., Zucolotto, M. E. \& Lopes, M. F. 2000: Petrography and Mineralogy of the Morro de La Mina Meteorite. Acta Microscopica 9/2: 53-58. 
Chikami, J. 2002: Mineralogical study of EET96077 and EET96309 enstatite chondrites. Lunar and Planetary Science XXXIII, Abstract No. 1083.

Curk, U. 2009: Mineralogija navadnih hondritov. Diploma thesis, University of Ljubljana, NTF (Ljubljana): 1-150.

Davis, A. M. 2005: Meteorites, Comets and Planets. Elsevier Pergamon (Oxford): 1-737.

Flood, P. G., Ashley, P. M. \& Pogson, R. E. 2002: The Dunbogan L6 Chondrite: a new meteorite fall from New South Wales, Australia. Records of the Australian Museum 54/2: 249-254.

Goldstein, J., Newbury, D., Joy, D., Lyman, C., Echlin, P., Lifshin, E., Sawyer, L. \& Michael, J. R. 2003: Scanning electron microscopy and $\mathrm{X}$-ray microanalysis, $3^{\text {rd }}$ edition. Kluwer Academic/Plenum Publishers (New York): 1-689.

Herd, R. K., Hunt, P. A. \& Venance, K. E. 2004: The systematic petrology of chondrites: A consistent approach to assist classification and interpretation. Workshop on Chondrites and Protoplanetary Disk, Abstract No. 9090.

Marfunin, A. S. 1998: Advanced Mineralogy: Mineral matter in space, mantle, ocean floor, bio- sphere, environmental management, and jewelry. Springer-Verlag (Berlin) 3: 31-444.

Middlehurst, B. M. \& Kuiper, G. P. 1963: The moon, meteorites and comets. The Solar System (in five volumes). The University of Chicago Press (Chicago and London): 1-810.

Nuth, J. A., Brearley, A. J. \& Scott, E. R. D. 2005 : Microcrystals and Amorphous Material in Comets and Primitive Meteorites: Keys to Understanding Processes. In: Krot, A. N., Scott, E. R. D. \& Reipurth, B. (eds.): Chondrites and the Protoplanetary Disk. ASP Conference Series 341: 675-700.

OXFORD INSTRUMENTS 2006: INCAEnergy EDS X-ray Microanalysis System. Oxford Instruments Analytical Limited (Oxfordshire): 1-19.

Reyes-Salas, A., Linares, C., Marcías-Romo, C. \& Ortega, F. 2007: An analytical SEM study of the stone meteorite Cosina. An ordinary chondrite H5. Acta Microscopica 16/1-2 (Supp. 2): 109110.

Zarek, W., Popiel, E. S., Tuszyński, M., Teper, E. \& ZareK, W. 2004: Mössbauer study of the El Hammami olivine-bronzite meteorite. Nukleonika 49 (Supp. 3): 59-62. 